\title{
PENGARUH KEPEMILIKAN MANAJERIAL, KEPEMILIKAN INSTITUSIONAL DAN KEPEMILIKAN PUBLIK TERHADAP NILAI PERUSAHAAN PADA PERUSAHAAN PROPERTI DAN REAL ESTATE YANG TERDAFTAR DI BURSA EFEK INDONESIA PERIODE 2016-2018
}

\author{
Imelda Purba \\ Fakultas Ekonomi Program Studi Akuntansi Accounting Universitas Katolik Santo Thomas \\ imelda.rimenda.purba@gmail.com
}

\begin{abstract}
ABSTRAK
Tujuan penelitian ini adalah untuk memperoleh bukti empiris pengaruh kepemilikan manajerial, kepemilikan institusional dan kepemilikan publik terhadap nilai perusahaan pada perusahaan property dan real estate periode 2016-2018. Jenis penelitian ini adalah penelitian kuantitatif. Data yang digunakan dalam penelitian ini adalah data sekunder. Populasi dalam penelitian ini meliputi seluruh perusahaan property dan real estate yang terdaftar di BEI periode 2016-2018. Sampel dalam penelitian ini sebanyak 16 perusahaan yang memenuhi kriteria. Teknik pengambilan sampel dalam penelitian ini menggunakan purposive sampling. Analisis data yang digunakan untuk menguji hipotesis adalah regresi berganda dengan taraf signifikansi 5\% dan menggunakan alat SPSS versi 23. Hasil penelitian ini menunjukkan bahwa variabel kepemilikan manajerial tidak berpengaruh terhadap nilai perusahaan, sedangkan kepemilikan institusional dan kepemilikan publik berpengaruh secara parsial terhadap nilai perusahaan. Kepemilikan manajerial, kepemilikan institusional, dan kepemilikan publik berpengaruh secara simultan terhadap nilai perusahaan.
\end{abstract}

Kata Kunci: Kepemilikan Manajerial, Kepemilikan Institusional, Kepemilikan Publik, Nilai Perusahaan.

\section{PENDAHULUAN}

Salah satu tujuan suatu perusahaan yang telah go public adalah untuk meningkatkan nilai perusahaannya melalui peningkatan kemakmuran pemilik atau para pemegang saham. Dalam suatu perusahaan, nilai perusahaan sangat penting karena nilai perusahaan mencerminkan keadaan atau kondisi serta kinerja suatu perusahaan. Nilai perusahaan dapat memberikan kemakmuran pemegang saham secara maksimum apabila harga saham meningkat, semakin tinggi harga saham sebuah perusahaan maka semakin tinggi tingkat kemakmuran pemegang saham (Mahendra et al.,2012). Nilai perusahaan sangat penting karena mencerminkan kinerja perusahaan yang dapat mempengaruhi persepsi investor terhadap perusahaan (Pramukti, et. al, 2019).

Setiap perusahaan tentunya memiliki struktur kepemilikan saham yang mencerminkan seberapa besar proporsi kepemilikan saham suatu perusahaan. Struktur kepemilikan atau insiders ownership adalah komposisi, porsi, perbandingan atau persentase antara modal, ekuitas termasuk saham yang dimiliki oleh orang di dalam perusahaan (insider shareholders) dan investor (outsite shareholders). Struktur kepemilikan dapat berupa investor individual, pemerintah, dan institusi swasta. Struktur kepemilikan merupakan bentuk komitmen dari pemegang saham untuk mendelegasikan pengendalian dengan tingkat tertentu kepada para manajer. Pemilik perusahaan akan menunjuk agenagen profesional yang telah terlebih dahulu dipilih melalui seleksi yang kemudian akan melaksanakan tugasnya untuk mengelola perusahaan yang pada akhirnya dituntutuntuk dapat memaksimalkan nilai perusahaan. Struktur kepemilikan perusahaan mempunyai pengaruh terhadap nilai perusahaan yang telah dibuktikan dari beberapa teori manajemen keuangan yang ada. Teori keagenan (Agency Theory) adalah suatu teori yang menjelaskan hubungan kerjasama antara principal (pemilik perusahaan) dan agent (manajemen perusahaan), dimana principal mendelegasikan wewenang kepada agent untuk 
mengelola perusahaan dan mengambil keputusan (Jensen dan Meckling, 1976). Agency theory menjelaskan bahwa konflik yang terjadi antara manajemen dan pemilik akan berpengaruh pada kinerja perusahaan sehingga sangat perlu dilakukan penyatuan kepentingan di antara kedua belah pihak (Shalini, 2020). Dalam penelitian Jensen and Meckling (1976) menyatakan bahwa "adanya konflik kepentingan antara manajemen dan pemilik dapat dipengaruhi oleh struktur kepemilikan yang meliputi kepemilikan manajerial dan kepemilikan institusional". Kepemilikan manajerial menggambarkan suatu peran ganda yaitu sebagai manajer dan juga pemegang saham dimana masing-masing memiliki kepentingan (Shalini, 2020). Keberadaan struktur kepemilikan institusional dapat mengurangi adanya agency problem maksudnya bahwa kepemilikan institusional memiliki arti penting dalammemonitor pihak manajemen yang berkaitan dengan kendali atas sumber daya perusahaan yang dipegang oleh manajer, jika ada kemungkinan manajer akan mengambil keputusan yang dapat merugikan pemegang saham dengan melakukan tindakan-tindakan yang memanfaatkan sumber daya perusahaan untuk kesejahteraannya sendiri.

Salah satu karakteristik struktur kepemilikan adalah konsentrasi kepemilikan yang terbagi dalam dua bentuk struktur kepemilikan, yaitu kepemilikan terkonsentrasi dan kepemilikan menyebar (Shinta dan Ahmar, 2011). Menurut Dallas (2004) dalam penelitian Shinta dan Ahmar (2011), menyatakan bahwa: "Kepemilikan saham dikatakan terkonsentrasi jika sebagian besar saham dimiliki oleh sebagian kecil individu atau kelompok, sehingga pemegang saham tersebut memiliki jumlah saham yang relatif dominan dibandingkan dengan yang lainnya. Kepemilikan saham dikatakan menyebar, jika kepemilikan saham menyebar secara relatif merata ke publik, tidak ada yang memiliki saham dalam jumlah sangat besar dibandingkan dengan yang lainnya”. Dalam penelitian Putri dan Nuzula (2018) menyatakan bahwa kepemilikan saham yang terkonsentrasi akan memudahkan pemegang saham untuk mengkoordinasikan tindakan dan informasi dari pihak manajemen sehingga dapat mencegah munculnya informasi asimetris. Sebaliknya, apabila kepemilikan saham tersebar maka akan menyulitkan pemegang saham dalam mengkoordinasikan tindakan dan informasi dari pihak manajemen. Menurut Baysinger et al., (1991), kepemilikan saham terkonsentrasi jika persentase kepemilikannya 0,2 persen atau lebih. Menurut Shleifer \& Vishny (1986), kepemilikan publik mencerminkan jumlah saham yang beredar di masyarakat. Semakin besar kepemilikan saham oleh publik, semakin banyak informasi yang diketahui publik tentang perusahaan tersebut. Dibandingkan dengan manajer yang sekaligus bertindak sebagai pemegang saham, dan pemegang saham institusional, pemegang saham publik memiliki pengaruh yang paling sedikit terhadap nilai perusahaan.

Investasi dalam bidang properti dan real estate sangat diminati masyarakat, karena selain memiliki nilai tambah yang tinggi, investasi pada bidang properti dan real estate dapat meningkatkan pendapatan tahunan, peningkatan nilai tanah, serta merupakan suatu investasi jangka panjang (Shalini,2020). Lesunya keadaan ekonomi dan gejolak nilai tukar rupiah terhadap dollar pada saat itu membuat pendapatan maupun laba bersih emiten sektor ini terus mengalami penurunan pada tahun 2015-2018. Rendahnya pertumbuhan properti membuat indeks harga sahamsektor ini pun ikut semakin menurun. Perlambatan ini disebabkan oleh rendahnya daya beli masyarakat, yang merupakan imbas dari keadaan ekonomi. Selain itu, dampak pelemahan nilai tukar rupiah terhadap dolar juga menjadi faktor penghambat pertumbuhan bisnis ini (Shalini, 2020).

Bukti empiris mengenai pengaruh kepemilikan manajerial, kepemilikan institusional, dan kepemilikan publik terhadap nilai perusahaan menunjukkan hasil yang berbeda-beda. Pada penelitian Shalini (2020) menemukan bahwa kepemilikan manajerial berpengaruh negatif dan tidak signifikan terhadap nilai perusahaan, sedangkan kepemilikan institusional berpengaruh positif dan signifikan terhadap nilai perusahaan. Penelitian Pramukti et, al (2019) menyatakan bahwa kepemilikan manajerial, kepemilikan institusional, dan kepemilikan publik berpengaruh positif dan signifikan terhadap nilai perusahaan. Adnantara (2013) menyatakan bahwa kepemilikan institusional dan kepemilikan publik tidak berpengaruh terhadap nilai perusahaan. Putri dan Nuzula (2018) menemukan bahwa kepemilikan publik berpengaruh terhadap nilai perusahaan. Arbi (2010) menyatakan bahwa kepemilikan institusional mayoritas (diatas 5\%) tidak berpengaruh terhadap nilai perusahaan, tetapi 
kepemilikan institusional minoritas (dibawah 5\%) dan kepemilikan publik berpengaruh terhadap nilai perusahaan. Sementara Sofyaningsih dan Hardiningsih (2011) menyatakan bahwa kepemilikan manajerial berpengaruh terhadap nilai perusahaan dan kepemilikan institusional tidak berpengaruh terhadap nilai perusahaan.

Untuk itu berdasarkan fenomena yang telah disebutkan dan perbedaan dari beberapa hasil penelitian sebelumnya, maka penulis tertarik untuk meneliti dan melihat kembali apakah kepemilikan manajerial, kepemilikan institusional dan kepemilikan publik mempunyai pengaruh terhadap peningkatan atau penurunan nilai perusahaan pada emiten properti dan real estate.

\section{TELAAH TEORI}

\subsection{Agency Theory}

Agency problem secara garis besar terjadi ketika manajer membuat sebuah keputusan yangtidak konsisten dengan tujuan untuk memaksimalkan kemakmuran pemegang saham sebagai tujuan umum sebuah perusahaan (Arbi, 2010). Manajer sebagai pihak yang diberi wewenang atas kegiatan perusahaan dan berkewajiban menyediakan laporan keuangan akan cenderung untuk melaporkan sesuatu yang memaksimalkan utilitasnya dan mengorbankan kepentingan pemegang saham (Permanasari, 2010). Sehingga muncullah konflik kepentingan antara pemilik (investor) dengan manajer (agent) (Fahmi, 2014). Perbedaan kepentingan pihak-pihak yang bersangkutan inilah menyebabkan terjadi konflik diantara keduanya. Menurut Vintilă \& Gherghina, 2015, sikap pihak manajemen perusahaan yang mengutamakan kepentingan pribadi tidaklah disukai pihak investor karena dengan mengutamakan kepentingan pribadi pihak manajemen perusahaan dapat menimbulkan pengeluran yang akan menambah biaya perusahaan yang menyebabkan penurunan keuntungan perusahaan yang akan diterima oleh investor.

Konflik antara manajer dan pemegang saham dapat diminimumkan dengan suatu mekanisme pengawasan yang dapat mensejajarkan kepentingan-kepentingan tersebut sehingga timbul biaya keagenan (agency cost). Ada beberapa alternatif untuk mengurangi agency cost, diantaranya adanya kepemilikan saham oleh institusional dan kepemilikan saham oleh manajemen (Permanasari, 2011). Menurut Gallagher (2000) menyatakan bahwa agency cost merupakan pengeluaran waktu dan uang yang dilakukan oleh perusahaan untuk mengurangi agency problem. Agency cost dapat dikurangi dengan meningkatkan level kepemilikan manajemen supaya mengurangi biaya monitoring. Agency cost yang lebih rendah diasosiasikan dengan nilai perusahaan yang semakin tinggi.

\subsection{Nilai Perusahaan}

Tujuan didirikannya sebuah perusahaan adalah untuk memaksimalkan kekayaan pemilik perusahaan yaitu untuk memaksimalkan nilai perusahaan. Nilai perusahaan ditentukan dengan seberapa banyak orang bersedia membayar untuk mendapatkan perusahaan tersebut, ketika seseorang memiliki anggapan bahwa perusahaan tersebut bernilai tinggi maka seseorang akan bersedia mengeluarkan/melakukan pengorbanan untuk mendapatkan perusahaan tersebut. Pemilik perusahaan tersebut ketika mengetahui bahwa perusahaannya dipandang memiliki nilai yang tinggi maka akan mampu menjualnya kepada investor dengan nilai lebih daripada harga beli semula yang berakibat meningkatnya kekayaan pemilik (Arbi, 2010). Nilai perusahaan sangat penting karena mencerminkan kinerja perusahaan yang dapat mempengaruhi persepsi investor terhadap perusahaan.

\subsection{Kepemilikan Manajerial}

Kepemilikan manajerial adalah persentase kepemilikan saham oleh pihak manajemen yang secara aktif ikut dalam pengambilan keputusan perusahaan (Shalini, 2020). Menurut Jensen dan Meckling (1976), ketika kepemilikan saham oleh manajemen rendah maka ada kecenderungan akan terjadinya perilaku opportunistic manajer yang meningkat juga. Dengan adanya kepemilikan manajemen terhadap saham perusahaan maka dipandang dapat menyelaraskan potensi perbedaan kepentingan antara manajemen dan pemegang saham lainnya sehingga permasalahan antara agen dan prinsipal diasumsikan akan hilang apabila seorang manajer juga sekaligus sebagai pemegangsaham. 


\subsection{Kepemilikan Institusional}

Kepemilikan institusional memiliki arti penting dalam mengawasi manajemen dengan pengawasan yang lebih optimal terhadap berbagai keputusan penting dalam perusahaan. Tingkat saham institusional yang tinggi akan menghasilkan upaya-upaya pengawasan yang lebih intensif (Shalini, 2020). Tingkat kepemilikan institusional yang tinggi akan menimbulkan usaha pengawasan yang lebih besar oleh pihak investor institusional sehingga dapat menghalangi perilaku opportunistic manajer. Semakin besar kepemilikan oleh institusi keuangan maka semakin besar pula kekuatan suara dan dorongan untuk mengoptimalkan nilai perusahaan (Arbi, 2020).

\subsection{Kepemilikan Publik}

Menurut Wijayanti (2009), kepemilikan publik adalah proporsi atau jumlah kepemilikan saham yang dimiliki oleh publik atau masyarakat umum yang tidak memiliki hubungan istimewa dengan perusahaan. Kepemilikan publik merupakan persentase kepemilikan saham yang dimiliki oleh pihak luar (outsider ownership). Adanya proporsi kepemilikan publik dalam struktur kepemilikan perusahaan akan memudahkan monitoring, intervensi, atau beberapa pengaruh kedisiplinan lain pada manajer. Oleh karena itu, konsentrasi kepemilikan publik dapat memberikan pengaruh terhadap keputusan strategis perusahaan (Putri dan Nuzula, 2018).

\section{Kerangka Teoritis Dan Hubungan Antar Variabel Pengaruh Kepemilikan Manajerial terhadap Nilai Perusahaan}

Adanya kepemilikan manajerial dalam sebuah perusahaan akan menimbulkan dugaan yang menarik bahwa nilai perusahaan meningkat sebagai akibat kepemilikan manajerial yang meningkat. Apabila kepemilikan saham oleh manajerial rendah maka ada kecenderungan akan terjadinya perilaku opportunistic manajer yang akan meningkat juga. Dengan adanya kepemilikan manajerial terhadap saham perusahaan maka dipandang dapat menyelaraskan potensi perbedaan kepentingan antara manajemen dan pemegang saham lainnya sehingga permasalahan antara agen dan prinsipal diasumsikan akan hilang apabila seorang manajer juga sekaligus sebagai pemegangsaham.

\section{Pengaruh Kepemilikan Institusional terhadap Nilai Perusahaan}

Investor institusional dapat disubstitusikan untuk melaksanakan fungsi monitoring mendisiplinkan penggunaan debt (utang) dalam struktur modal. Semakin besar kepemilikan institusional maka semakin efisien fungsi monitoring terhadap manajemen dalam pemanfaatan asset perusahaan serta pencegahan pemborosan oleh manajemen (Adnantara, 2013). Pengawasan tersebut menjamin kemakmuran para pemegang saham karena dengan adanya kepemilikan institusional sebagai agen pengawas melalui investasi mereka yang cukup besar dalam pasar modaldapat ikut membuat suatu keputusan dalam perusahaan (Fahmi, 2014). Disamping itu, melalui usaha-usaha yang positif, investor institusional akan berusaha untuk meningkatkan nilai perusahaan yang dimilikinya (Haruman, 2008).

\section{Pengaruh Kepemilikan Publik terhadap Nilai Perusahaan}

Menurut Wulan (2015) kepemilikan publik adalah kepemilikan saham oleh masyarakat umum atau oleh pihak luar. Kepemilikan saham oleh publik umumnya dapat bertindak sebagai pihak yang memonitor perusahaan. Perusahaan dengan kepemilikan publik yang besar (lebih dari $5 \%$ ) akan mempengaruhi secara parsial dalam nilai perusahaan (Siburian, et. al, 2018). 


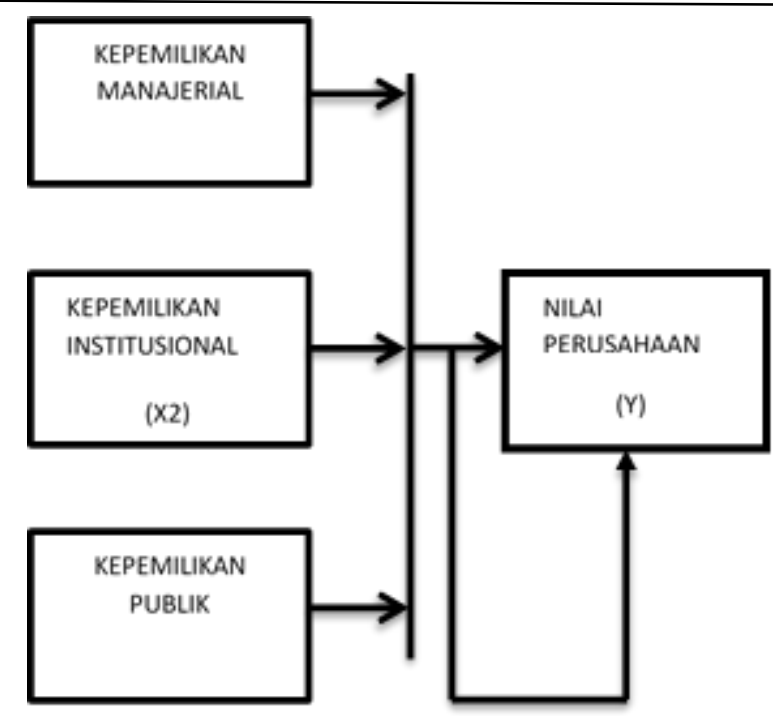

Gambar 1 Pengaruh Variabel

\section{Hipotesis}

Hipotesis adalah jawaban sementara atas masalah yang telah dirumuskan. Dari penjelasan teoridan perumusan masalah diatas, maka Hipotesis dirumuskan sebagai berikut :

1. Kepemilikan Manajerial berpengaruh positif terhadap Nilai Perusahaan

2. Kepemilikan Institusional berpengaruh positif terhadap Nilai Perusahaan

3. Kepemilikan Publik berpengaruh positif terhadap Nilai Perusahaan

4. Kepemilikan Manajerial, Kepemilikan Institusional, dan Kepemilikan Publik berpengaruh positif terhadap Nilai Perusahaan secara simultan.

\section{TUJUAN DAN MANFAAT PENELITIAN}

\section{Tujuan Penelitian}

Tujuan yang ingin dicapai dalam penelitian ini :

1. Untuk membuktikan secara empiris pengaruh kepemilikan manajerial terhadap nilai perusahaan.

2. Untuk membuktikan secara empiris pengaruh kepemilikan institusional terhadap nilai perusahaan.

3. Untuk membuktikan secara empiris pengaruh kepemilikan publik terhadap nilai perusahaan.

4. Untuk membuktikan secara empiris pengaruh kepemilikan manajerial, kepemilikan institusional, dan kepemilikan publik secara simultan terhadap nilai perusahaan pada perusahaan properti dan real estate yang terdaftar di BEI periode 2016-2018.

\section{Manfaat Penelitian}

Hasil penelitian ini diharapkan dapat bermanfaat :

1. Memberikan informasi yang bisa digunakan sebagai bahan pertimbangan oleh manajemen emiten untuk menyikapi struktur kepemilikan yang mempengaruhi nilai perusahaan yang terdaftar di bursa efek.

2. Menyediakan informasi kepada para praktisi bisnis khususnya investor dan para kreditur dalam melihat gambaran tentang nilai perusahaan.

3. Memberikan arah studi tentang nilai perusahaan dan struktur kepemilikan.

\section{METODOLOGI PENELITIAN Desain Penelitian}


Desain dalam penelitian adalah salah satu cara yang sifatnya sistematik dan objektif dengan tujuanuntuk memperoleh, mengumpulkan informasi atau data-data yang diteliti secara efisien, yang dapat digunakan sebagai pedoman dalam melaksanakan penelitian. Metode penelitian ini meliputi: populasi dan sampel, operasional variabel, teknik pengumpulan data, teknik analisis dan hipotesis.

\section{Populasi dan Sampel}

Menurut Sugiyono (2011) populasi adalah wilayah generalisasi yang terdiri atas objek/subjek yang memiliki kualitas dan karakteristik tertentu yang ditetapkan oleh peneliti untuk dipelajari dan ditarik kesimpulannya. Populasi dalam penelitian ini adalah perusahaan properti dan real estate yang terdaftar di Bursa Efek Indonesia periode 2016-2018. Sesuai dengan pengklasifikasian Indonesian Capital Market Directory tahun 2016-2018.

Menurut Sugiyono (2011) sampel adalah bagian dari jumlah dan karakteristik yang dimilikioleh populasi tersebut. Penelitian ini menggunakan teknik purposive sampling. Purposive sampling adalah teknik mengambil sampel dari populasi yang diperkirakan paling cocok untuk dikumpulkan datanya dan pengambilan data disesuaikan dengan kriteria-kriteria yang telah ditentukan. Sampel yang diteliti adalah 16 perusahaan, sehingga pengamatan yang dijadikan sampel adalah sebanyak $(16 \times 3$ tahun $)=$ 48 pengamatan.

\section{Operasionalisasi Variabel}

Variabel penelitian adalah suatu atribut atau sifat atau nilai dari orang atau objek yang mempunyai variasi antara satu dengan yang lainnya dalam kelompok itu (Sugiyono,2011).

Variabel-variabel yang dipakai dalam penelitian ini sebagai berikut :

1. Kepemilikan manajerial yang diproksi dengan Managerial Ownership (MOWN) merupakan presentase kepemilikan saham oleh pihak manajer perusahaan terhadap jumlah saham yang beredar yang menunjukkan persentase kepemilikan saham oleh pihak manajemen yang secara aktif ikut dalam pengambilan keputusan perusahaan (Shalini, 2020).

2. Kepemilikan institusional yang diproksi dengan Institutional Ownership (INSWN). Rasio ini mengukur persentase kepemilikan saham oleh pihak institusional perusahaan terhadap jumlah saham beredar (Shalini, 2020).

3. Kepemilikan publik yang diproksi dengan Public Ownership (POWN). Rasio ini mengukur persentase kepemilikan saham oleh pihak publik (pihak luar) perusahaan terhadap jumlah saham beredar (Wijayanti, 2009)

4. Nilai perusahaan dalam penelitian ini diukur dengan Price to Book Value (PBV) ratio. MenurutTui et al., (2017) Price to Book Value (PBV) ratio adalah suatu rasio untuk menentukan nilai perusahaan dan mengambil keputusan investasi dengan cara membandingkan nilai pasar saham dengan nilai buku per lembar saham.

\section{Teknik Pengumpulan Data}

Teknik pengumpulan data yang digunakan dalam penelitian ini adalah teknik dokumentasi.Data yang digunakan dalam penelitian ini adalah data sekunder, yakni adalah laporan keuangan (audit) perusahaan Properti dan Real Estate tahun 2016 sampai dengan tahun 2018 yang diperoleh dari situs resmi BEI, yaitu www.idx.co.id yang terdiri dari variabel Kepemilikan Manajerial, Kepemilikan Institusional, dan Kepemilikan Publik terhadap Nilai Perusahaan.

\section{Metode Analisis}

Dalam penelitian ini, metode analisis data yang digunakan adalah metode analisis statistik dengan menggunakan software SPSS. Sebelum data dianalisis, maka untuk keperluan analisis data tersebut, terlebih dahulu dilakukan uji asumsi klasik sebelum melakukan pengujian hipotesis. Untuk pengujian hipotesis dilakukan analisis regresi linier berganda.

Pengujian hipotesis yang digunakan dalam penelitian diuji adalah dengan menggunakan analisis 
regresi linier berganda. Model regresi yang digunakan adalah sebagai berikut :

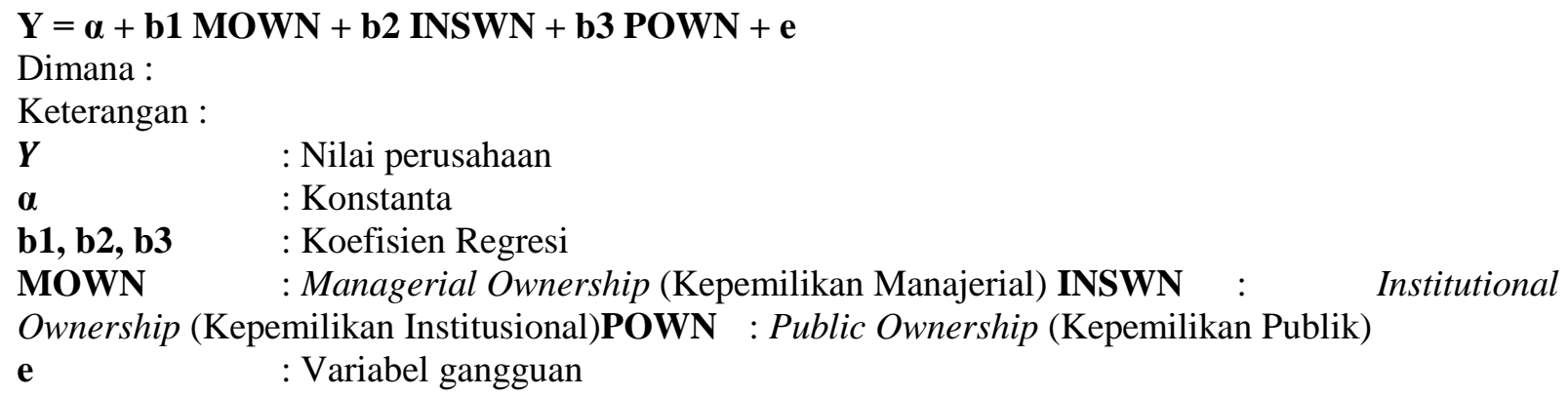

Uji Hipotesis

Pengujian Hipotesis adalah sebagai berikut :

1. Pengujian Hipotesis Secara Simultan (Uji-F)

Menurut Ghozali (2006) uji F digunakan untuk menunjukkan apakah semua variabel independen yang dimasukkan dalam model mempunyai pengaruh secara bersama-sama terhadap variabel dependen.

\section{Pengujian Hipotesis Secara Parsial (Uji-t)}

Uji t digunakan untuk menguji tingkat signifikansi pengaruh variabel independen terhadap variabel dependen secara parsial. Pengambilan keputusan dilakukan berdasarkan perbandingan nilai t hitung masing-masing koefisien $t$ regresi dengan $t$ tabel sesuai dengan tingkat signifikansi yang digunakan.

\section{Kriteria pengujian:}

$P$ Value (Sig) $>0,05$ dan nilai koefisien parameternya positif $=$ Ho (terima Ho tolak H1) dan tidak dapat memoderasi.

$P$ Value $(\mathrm{Sig})<0,05$ dan nilai koefisien parameternya negatif $=\mathrm{H} 1$ (terima $\mathrm{H} 1$ tolak Ho) dapat memoderasi.

\section{HASIL PENELITIAN DAN PEMBAHASAN Gambaran Umum Objek Penelitian}

Salah satu sektor perusahaan yang sangat berkembang pesat dan memiliki persaingan cukup ketat yang terdaftar di BEI adalah perusahaan sektor properti dan real estate. Investasi dalam bidang properti dan real estate sangat diminati masyarakat, karena properti dan real estate memiliki nilai tambah yang tinggi, dapat meningkatkan pendapatan tahunan, adanya peningkatan nilai tanah, serta merupakan investasi jangka panjang.

Perusahaan properti ini dalam perkembangannya merupakan usaha yang padat modal artinya likuiditas perusahaan merupakan faktor utama, hal ini dikarenakan dari sejak awal dalam usaha properti sudah sarat dengan kebutuhan dana yang tinggi dan perlu pengelolaan yang efisiendan efektif, yaitu mulai dari pengadaan bahan baku berupa tanah, biaya kontruksi, biaya operasional termasuk biaya marketing/ promosi, biaya ijin-ijin, dan lain-lain.

Kinerja emiten properti sepanjang tahun 2015-2018 mengalami perlambatan lantaran dihadapkan dengan tantangan berat. Lesunya kondisi ekonomi dan gejolak nilai tukar rupiah terhadap dollar membuat pendapatan maupun laba bersih emiten sektor ini tergerus. Rendahnya pertumbuhan properti membuat indeks harga saham sektor ini semakin menurun. Perlambatan di sektor properti dan real estate ini terjadi karena rendahnya daya beli masyarakat, yang merupakan imbas dari kodisi ekonomi. Selain itu, dampak pelemahan nilai tukar rupiah terhadap dolar juga menjadi faktor penghambat pertumbuhan bisnis ini (Shalini, 2020). Maka dari itu, penulis tertarik untuk menjadikan perusahaan properti dan real estate sebagai objek penelitian.

\section{Hasil Uji Asumsi Klasik}


Syarat dalam menggunakan model regresi berganda dengan metode Ordinary Least Square (OLS) adalah terpenuhinya semua asumsi klasik agar hasil pengujian tidak bersifat bias dan efisien(Best Linear Unbiased Estimator/BLUE). Uji asumsi klasik yang dilakukan dalam penelitian ini antara lain uji normalitas dan uji multikolinearitas.

\section{Uji Normalitas}

Uji normalitas dilakukan untuk mendeteksi apakah residual mempunyai distribusi normal atau tidak. Metode yang digunakan untuk uji normalitas adalah uji Jarque-Bera. Jika nilaiprobabilitas lebih besar dari taraf signifikansi 0,05 maka dihasilkan residual yang berdistribusi normal. Sebaliknya apabila nilai probabilitas lebih kecil dari taraf signifikansi 0,05 dapat diartikan bahwa residual tidak berdistribusi normal. Berikut merupakan hasil dari uji Jarque-Bera:

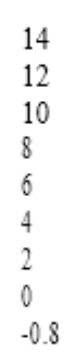

Tabel 1 . Uji Jarque-Bera

Dari tabel 1. dapat kita ketahui bahwa nilai probabilitas adalah 0,889424. Nilai probabilitas ini $>$ taraf sifgnifikansi 0,05 yang menyatakan bahwa residual berdistribusi dengan normal.

\section{Uji Multikolinearitas}

Uji multikolinearitas bertujuan untuk menguji apakah pada model regresi ditemukan adanya korelasi antar variabel independen. Pada model regresi yang baik seharusnya tidak terjadi korelasiantar variabel independen. Pengujian multikolinearitas dilakukan dengan melihat VIF antarvariabel independen.

\section{Tabel 2. Uji Multikolinearitas}

\begin{tabular}{|ll|l|l|}
\hline \multirow{2}{*}{ Model } & \multicolumn{2}{|l|}{ Collinearity Statistics } \\
\cline { 2 - 4 } & Tolerance & VIF \\
\hline 1 & (Constant) & & \\
& MOWN & .857 & 1.166 \\
& INSWN & .988 & 1.012 \\
PCWN & .988 & 1.012 \\
\hline
\end{tabular}

Sumber : Hasil Pengolahan Data, 2021

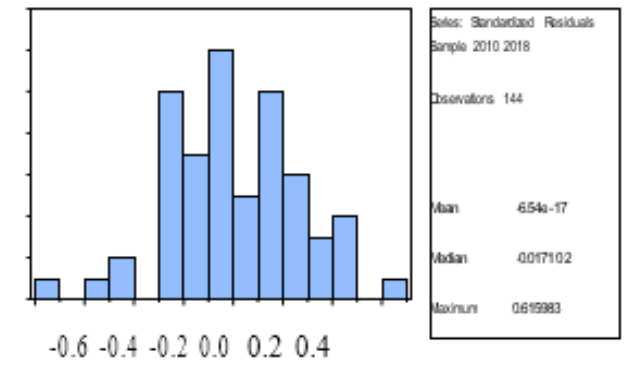

Hasil uji multikolinearitas menunjukkan ketiga variabel independen Kepemilikan Manajerial, Kepemilikan Institusional, dan Kepemilikan Publik tidak terjadi multikolinearitas karena nilai tolerance ketiga variabel independen berada di atas 0,10 dan nilai VIF ketiga variabel independen berada di bawah 10 .

\section{Uji Autokorelasi}

Pada penelitian ini, uji autokorelasi dilakukan dengan menggunakan uji Durbin-Watson.

\section{Tabel 3. Uji Autokorelasi}

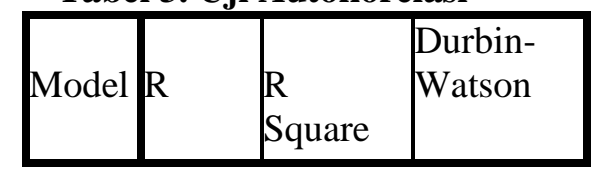


Sumber : Hasil Pengolahan Data, 2021

\section{\begin{tabular}{|l|l|l|}
\hline $.878^{\mathrm{a}}$ & .643 & .685 \\
\hline
\end{tabular}}

Hasil uji autokorelasi menunjukkan nilai Durbin-Watson sebesar 0,685; sedangkan dalam tabel DW untuk "k" = 3 (variabel bebas, tidak termasuk variabel terikat) besar nilai dl (batas bawah) =1,4064 dan du (batas atas) $=1,6708 ; 4-\mathrm{du}=2,3292$ dan $4-\mathrm{dl}=2,5936$. Dengan melihatkriteria pada pedoman Durbin-Watson 0,685<2,5936 maka hasil test Uji tidak terjadi autokorelasi.

\section{Pengujian Hipotesis}

Regresi linear Kepemilikan Manajerial, Kepemilikan Institusional, dan Kepemilikan Publik terhadap Nilai Perusahaan pada sektor Properti dan Real Estate yang terdaftar di BEI

Untuk mendapatkan hasil regresi antara variabel independent (Kepemilikan Manajerial, Kepemilikan Institusional, dan Kepemilikan Publik) dan variabel dependen (Nilai Perusahaan) maka digunakan data sekunder yang berasal dari BPS yang dicatat mulai dari tahun 2016-2018 dan diolah dengan menggunakan bantuan program komputer. Berikut ini hasil pengolahan data dengan menggunakan metode OLS (Ordinary Least Square).

Tabel 4. Hasil Regresi

Sumber : Hasil Pengolahan Data, 2021

\begin{tabular}{|c|l|l|l|l|}
\hline \multirow{2}{*}{ Model } & \multicolumn{2}{|l|}{$\begin{array}{l}\text { Unstandardized } \\
\text { Coefficients }\end{array}$} & & \\
\cline { 2 - 4 } & $\mathrm{B}$ & Std. Error & & \multirow{2}{*}{ Sig. } \\
\hline 1 (Constant) & 3.237 & .686 & 4.718 & .000 \\
MOWN & 3.744 & .000 & .294 & .770 \\
INSWN & 4.449 & 3.211 & 2.386 & .003 \\
PCWN & 3.808 & 1.525 & 2.497 & .016 \\
\hline
\end{tabular}

Dari hasil regresi diatas, dapat dibentuk model hasil estimasi sebagai berikut : $\mathrm{Y}=3,237+4,449 \mathrm{X} 1+$ 3,744 X2 + 3,808 X3

\section{Interpretasi Model}

Berdasarkan model estimasi diatas dapat dijelaskan pengaruh variabel independent yaitu suku bunga Pengeluaran Pemerintah Sektor Kepemilikan Manajerial (X1), Kepemilikan Institusional (X2) dan Kepemilikan Publik (X3) terhadap Nilai Perusahaan (Y) Pada Perusahaan Properti dan Real Estate yang terdaftar di BEI sebagai berikut :

Konstanta sebesar 3,237 menyatakan bahwa jika kepemilikan manjerial, kepemilikan institusional, dan kepemilikan publik bernilai 0 maka nilai perusahaan bertambah sebesar 3,237.

1. Koefisien regresi kepemilikan manajerial sebesar 3,744 menyatakan bahwa setiap kenaikan 1 satuan kepemilikan manajerial akan menyebabkan peningkatan nilai perusahaan sebesar 3,744.

2. Koefisien regresi kepemilikan institusional sebesar 4,449 menyatakan bahwa setiap kenaikan kepemilikan institusional 1 satuan akan menyebabkan peningkatan nilai perusahaan sebesar 4,449 .

3. Koefisien regresi kepemilikan publik sebesar 3,808 menyatakan bahwa setiap kenaikan kepemilikan publik 1 satuan akan menyebabkan peningkatan nilai perusahaan sebesar 3,808.

\section{Pengujian Koefisien Regresi Secara Individual (Uji t Statistik)}

1. Hasil perhitungan uji $\mathrm{t}$ secara parsial diperoleh nilai t hitung kepemilikan manajerial sebesar 0,294 dengan nilai signifikan sebesar 0,770. Nilai t hitung < t tabel atau 0,294<2,013 maka H0 diterima artinya kepemilikan manajerial tidak berpengaruh positif terhadap nilai perusahaan pada perusahaan Properti dan Real Estate di Bursa Efek Indonesia periode 2016- 2018.

2. Hasil perhitungan uji t secara parsial diperoleh nilai t hitung kepemilikan institusional sebesar 
2,386 dengan nilai signifikan sebesar 0,003. Nilai t hitung > t tabel atau 2,386 > 2,013 maka Ha diterima artinya kepemilikan institusional berpengaruh positif terhadap nilai perusahaan pada perusahaan Properti dan Real Estate di Bursa Efek Indonesia periode 2016-2018.

3. Hasil perhitungan uji t secara parsial diperoleh nilai t hitung kepemilikan publik sebesar - 2,497 dengan nilai signifikan sebesar 0,016. Nilai t hitung > t tabel atau 2,497 > 2,013 maka Ha diterima artinya kepemilikan publik berpengaruh positif terhadap nilai perusahaan pada perusahaan Properti dan Real Estate di Bursa Efek Indonesia periode 2016-2018.

\section{Pengujian Koefisien Regresi Secara Bersamaan (Uji F Statistik) Tabel 5 Uji Anova}

Sumber : Hasil Pengolahan Data, 2021

\begin{tabular}{|ll|l|l|l|}
\hline Model & $\begin{array}{l}\text { Mean } \\
\text { Square }\end{array}$ & F & Sig. \\
\hline 1 & $\begin{array}{l}\text { Regression } \\
\text { Residual } \\
\text { Total }\end{array}$ & 22.422 & 3.745 & $.031^{\mathrm{b}}$ \\
\hline
\end{tabular}

Berdasarkan tabel diatas maka uji signifikansi simultan / bersama-sama (uji statistik F) menghasilkan nilai $\mathrm{F}$ hitung sebesar 3,745. Pada derajat bebas $1(\mathrm{df} 1)=\mathrm{k}-1=4-1=3$, dan derajat bebas $2(\mathrm{df} 2)=$ $\mathrm{n}-\mathrm{k}=48-4=44$, dimana $\mathrm{n}=$ jumlah sampel, $\mathrm{k}=$ jumlah variabel, nilai $\mathrm{F}$ tabel pada taraf kepercayaan signifikansi 0,05 adalah 2,82 dengam demikian $\mathrm{F}$ hitung $=3,745>\mathrm{F}$ tabel $=2,82$ dengan tingkat signifikansi 0,031. karena probabilitasnya signifikansi jauh lebih kecil dari sig atau $0,031<0,05$, Maka Ha diterima artinya secara bersama-sama kepemilikan manajerial, kepemilikan institusional, dan kepemilikan publik berpengaruh terhadap nilai perusahaan pada perusahaan Properti dan Real Estate di Bursa Efek Indonesia periode 2016-2018.

Koefisien Determinasi (R2)

Tabel 6. Uji Koefisien Determinasi



Sumber : Hasil Pengolahan Data, 2021

Hasil Uji Koefisien Determinasi diperoleh nilai $R$ square sebesar 0,643 hal ini berarti 64,3

$\%$ dari variasi variabel dependen nilai perusahaan yang dapat dijelaskan oleh variabel independen kepemilikan manajerial, kepemilikan institusional, dan kepemilikan publik sedangkan sisanya sebesar $35,7 \%$ dijelaskan oleh variabel-variabel lain diluar variabel penelitian.

\section{KESIMPULAN DAN SARAN}

\section{Kesimpulan}

1. Dari hasil uji F, disimpulkan bahwa Kepemilikan Manajerial, Kepemilikan Institusional, dan Kepemilikan Publik selama periode 2016 sampai dengan 2018 berpengaruh signifikan secara simultan terhadap nilai perusahaan pada perusahaan Properti dan Real Estate di Bursa Efek Indonesia pada tingkat signifikansi 5\%. Dengan demikian hipotesis penelitian diterima.

2. Berdasarkan uji parsial (uji t), variabel Kepemilikan Institusional dan Kepemilikan Publik berpengaruh nyata secara parsial sedangkan variabel Kepemilikan Manajerial tidak berpengaruh nyata terhadap variabel nilai perusahaan pada perusahaan Properti dan Real Estate di Bursa Efek Indonesia dengan pengujian pada tingkat kepercayaan $95 \%(\square=5 \%)$.

3. Nilai koefisien determinasi (R) sebesar 0,643 yang berarti bahwa variabel X1 (Kepemilikan 
Manajerial), X2 (Kepemilikan Institusional), dan X3 (Kepemilikan Publik) secara bersama-sama mampu memberikan penjelasan variasi Nilai Perusahaan sebesar 64,3\% sedangkan sisanya $35,7 \%$ dijelaskan oleh variabel baru yang tidak disertakan dalam estimasi model.

\section{Saran}

1. Berdasarkan keterbatasan penelitian ini, maka bagi peneliti selanjutnya yang ingin meneliti tentang Nilai Perusahaan disarankan dapat menambah variabel-variabel lainnya terhadap Variabel Kinerja Keuangan, GCG, CSR, dan lain-lain.

2. Peneliti hanya menggunakan Nilai Perusahaan sebagai variabel dependen, padahal mungkin saja ada variabel lain yang dapat dipengaruhi oleh Kepemilikan Manajerial, Kepemilikan Institusional, dan Kepemilikan Publik ataupun juga mungkin ada variabel lain yang berada diantara variabel independen dan dependen (variabel antara). Dan jika variabel antara tersebut dimasukkan dalam model penelitian, mungkin akan memberikan hasil yang lebih komprehensif.

\section{DAFTAR PUSTAKA}

Adnantara,Komang Fridagustina. (2013). Pengaruh Struktur Kepemilikan Saham Dan Corporate Social

Responsibility Pada Nilai Perusahaan. Jurnal Buletin Studi Ekonomi. Vol 18(2).

Arbi,Fanny Hanadi. (2010). Pengaruh Kepemilikan Institusional dan Kepemilikan Publik Terhadap Nilai Perusahaan Pada Perusahaan Yang Terdaftar di Bursa Efek Indonesia. Universitas Sebelas Maret.

Baysinger, Barry D, Rita D. Kosnik, dan Thomas A.Turk. 1991. Effects of Board and Ownership Structure on Corporate R\&D Strategy. Academy of Management Journal, Vol. 34, No. 1: 205214

Fahmi, I. (2014). Manajemen Keuangan Perusahaan. Mitra Wacana Media.

Gallagher, Timothy. J. and Andrew, Joseph D. 2000. Financial Management. Prentice Hill

Ghozali, Imam. (2006). Aplikasi Analisis Multivariate dengan Program SPSS. Semarang : UNDIP

Haruman. (2008). Struktur Kepemilikan, Keputusan Keuangan, dan Nilai Perusahaan. Finance and Banking Journal, 10(2), 150-166.

Jensen, M. C., \& Meckling, W. H. (1976). Theory Of The Firm: Managerial Behavior, Agency Costs And Ownership Structure. Journal of Financial Economics, 3, 305-360. https://doi.org/10.1177/0018726718812602

Mahendra, A., Artini, L. G. S., \& Suarjaya, A. . G. (2012). Pengaruh Kinerja Keuangan terhadap Nilai Perusahaan dengan Kebijakan Dividen sebagai Variabel Pemoderasi. Jurnal Manajemen, $\begin{array}{llll}\text { Strateg Bisnis, Dan } & \text { Kewirausahaan, } & 6 & \text { (2), }\end{array}$ https://doi.org/10.1017/CBO9781107415324.004

Permanasari,Wien Ika. (2010). Pengaruh Kepemilikan Manajemen, Kepemilikan Institusional, dan Corporate Social Responsibility Terhadap Nilai Perusahaan. Universitas Diponegoro.

Pramukti,Andika, Ashoer,Muhammad, Fadhil,Muhammad. (2019). Analisi Pengaruh Struktur Kepemilikan terhadap Profitabilitas dan Nilai Perusahaan pada Perusahaan yang Terdaftar di 
BEI.Paradoks : Jurnal Ilmu Ekonomi Vol 2 (2).

Putri,Nelly Sulistyani, Nuzula,Nila Firdausi. (2018). Pengaruh Konsentrasi Kepemilikan Publik Terhadap Investasi Research and Development Serta Dampaknya Terhadap Nilai Perusahaan. Jurnal Administrasi Bisnis (JAB). Vol 55(1). 204.

Shalini,Witya, Erlina, Lumbanraja,Prihatin. (2020). The Effect of Ownership Structure and Financial Performance on Firm Value with Dividend Policy as Moderating Variable at Property and Real Estate Companies. International Journal Of Innovative Science and Research Technology(ISSN 2456-2165), 5(7). https://doi.org/10.38124/IJISRT20JUL542

Shinta,Nendy Pramita, Ahmar,Nurmala. (2011). Eksplorasi Struktur Kepemilikan Saham Publik Di Indonesia Tahun 2004-2008. The Indonesian Accounting Review. Vol 1(2). 145-154.

Shleifer, A., \& Vishny, R. W. (1986). Large Shareholders and Corporate Control. Journal of Political Economy, 94(3, Part 1), 461-488. https://doi.org/10.1086/261385

Siburian,Roma R, Makhdalena, Riadi,R.M. (2018). Influence Of Foreign Ownership And Public Ownership on Firm Value In Transportation Companies Listed In Indonesia Stock Exchange. JOM FKIP. Vol 5(2).

Sugiyono. (2011). Metode Penelitian Kuantitatif, Kualitatif dan R\&D. Alfabeta.

Vintilă, G., \& Gherghina, Ş. C. (2015). Does ownership structure influence firm value? An empirical research towards the bucharest stock exchange listed companies. International Journal of Economics and Financial Issues, 5(2), 501-514.

Wijayanti,Ngestiana. (2009). Pengaruh Profitabilitas, Umur Perusahaan, Ukuran Perusahaan, dan Kepemilikan Publik Terhadap Ketepatan Waktu Pelaporan Keuangan Perusahaan. Universitas Sebelas Maret.

Wulan Aminatus Sholichah. 2015.Pengaruh Struktur Kepemilikan, Ukuran Perusahaan Dan Leverage Terhadap Nilai Perusahaan.Jurnal Ilmu \& Riset Akuntansi Vol. 4 No. 10

www.bapepam.go.id.

www.idx.co.id 